\title{
Therapeutic importance of sulfated polysaccharides from seaweeds: updating the recent findings
}

\author{
Seema Patel
}

Received: 22 January 2012/ Accepted: 29 March 2012/Published online: 15 April 2012

(C) The Author(s) 2012. This article is published with open access at Springerlink.com

\begin{abstract}
Seaweeds, being prolific sources of bioactive components have garnered unprecedented interest in recent times. The complex polysaccharides from the brown, red and green seaweeds possess broad spectrum therapeutic properties. Especially, the sulfated polysaccharides, viz. fucans, carrageenans and ulvans have exhibited strong antioxidant, antitumor, immunostimulatory, anti-inflammatory, pulmonary fibrosis anticoagulant/antithrombotic, lipid lowering, antiviral, antibacterial, antiprotozoan, hyperplasia prevention, gastrointestinal, regenerative and nano medicine applications. Considering the immense biomedical prospects of sulfated polysaccharides, the profound and emerging functional properties published in recent times will be discussed here with experimental evidences. The limitations of the seaweed-derived sulfated polysaccharides in healthcare will be summarized. Strategies to maximize extraction and bioavailability will be pondered.
\end{abstract}

Keywords Sulfated polysaccharides · Antioxidant · Antitumor · Anticoagulant · Antiviral

\section{Introduction}

In recent years, much attention has been focused on polysaccharides isolated from natural sources. During the last decade, numerous bioactive polysaccharides with interesting functional properties have been discovered from seaweeds (Fig. 1). Several algal species belonging to

S. Patel $(\square)$

Department of Biotechnology, Lovely Professional University, Jalandhar 144402, Punjab, India

e-mail: seemabiotech83@gmail.com phaeophyta, rhodophyta and chlorophyta divisions have been recognized as crucial sources of sulfated polysaccharides (SP). These SP constitute an important ingredient of cell walls and get harvested by suitable extraction or precipitation method, followed by purification, characterization and biological studies (Fig. 2). The biological features of the SP reported till now are antioxidant, antitumor, immunomodulatory, inflammation, anticoagulant, antiviral, antiprotozoan, antibacterial, antilipemic. Currently, the regenerative medicine and tissue engineering application of the SP has become a hot research area. Jiménez-Escrig et al. (2011) have reviewed the vital role of SP from seaweeds in human health.

Bioactive SP extracted from seaweeds can be classified into three types. The major fucan yielding brown seaweeds genera are Fucus, Sargassum, Laminaria, Undaria, Lessonia, Dictyota, Dictyopteris, Ascophyllum, Eclonia, Canistrocarpus, Lobophota, Turbinaria, Padina, Adenocystis, Sphacelaria, Cystoseira, etc. Fucan represents a family of water soluble, SP rich in sulfated L-fucose, extracted from extracellular matrix of these weeds ( $\mathrm{Li}$ et al. 2008; Costa et al. 2011a). Fucoidan, the sulfated alpha-Lfucan (term often interchangeably used with fucans) has demonstrated a wide range of pharmacological activities. Carrageenans are a family of linear SP, extracted from red seaweeds, viz. Gracialaria, Gigartina, Gelidium, Lomentaria, Corallina, Champia, Solieria, Gyrodinium, Nemalion, Sphaerococcus, Boergeseniella, Sebdenia, Scinaia, etc. This group of polysaccharides has a backbone of alternating 3-linked $\beta$-D-galactose and 4-linked $\alpha$-D-galactose residues (Tuvikene et al. 2006). Three categories of carrageenans, kappa $(\kappa)$, iota $(l)$, and lambda $(\lambda)$ have been identified till now based on their sulfation degree, solubility and gelling properties (Leibbrandt et al. 2010). Ulvan is the major water soluble, sulfated polysaccharide, extracted 

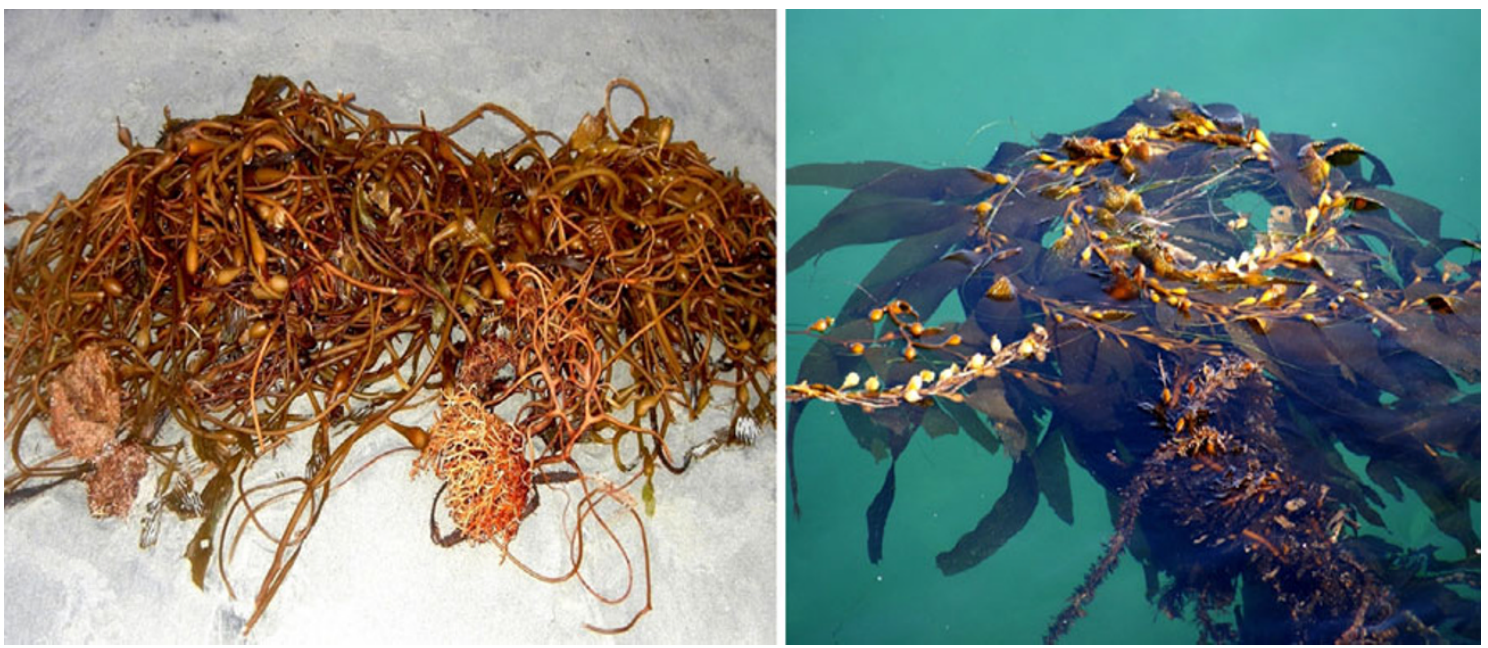

Fig. 1 Seaweeds growing on the California Coast of the Pacific Ocean

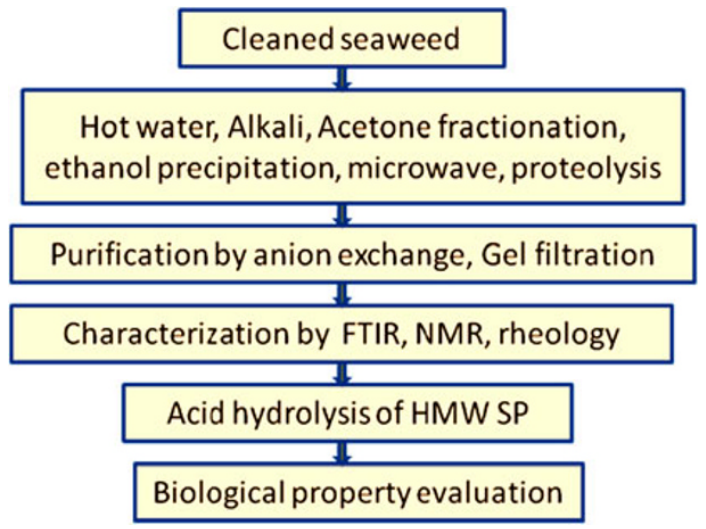

Fig. 2 A flowchart depicting the sequential steps for sulfated polysaccharide preparation and biological activity evaluation

from the cell wall of green algae, viz. Ulva, Enteromorpha, Monostroma, Caulerpa, Codium, Gayralia. Ulvans are composed of disaccharide repetition moieties made up of sulfated rhamnose linked to either glucuronic acid, iduronic acid, or xylose and represent about 8-29\% of the algal dry weight (Lahaye and Robic 2007). The above-described SP have been illustrated in Fig. 3.

The therapeutic mechanisms of these SP vary, hence it is yet to be studied precisely. For anticoagulation potency, the formation of the SP/protease protein complex and the associated non-specific polar interaction between the negatively and positively charged groups in the polysaccharide and protein is responsible for anticoagulant activity. The anticoagulant activity is mainly attributed to thrombin inhibition mediated by heparin cofactor II, with different effectiveness depending on the compound. Similarly, selectin blockade, inhibition of enzyme and complement cascade seem to be the triggers leading to anti-inflammation. Combating viral infection has been shown by

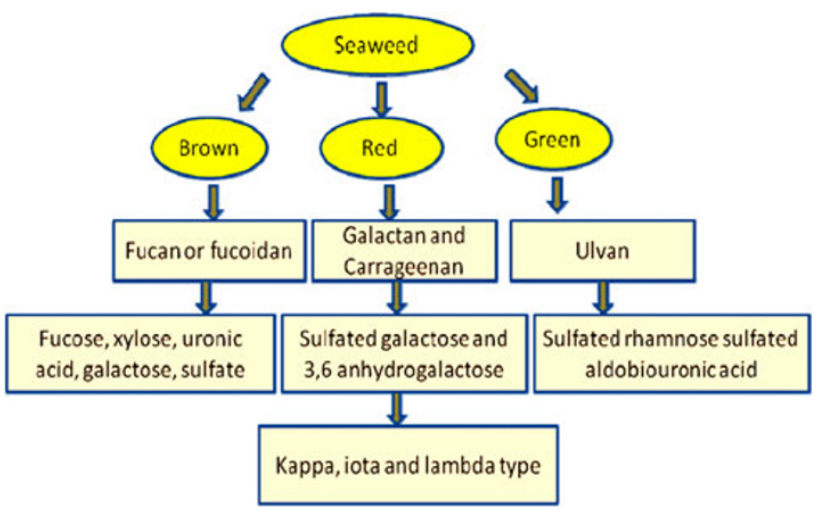

Fig. 3 Classification of the bioactive sulfated polysaccharides

adsorption and internalization steps (Kim et al. 2011, 2012).

Ion exchange, gel filtration, FTIR, NMR analyses are employed to elucidate the composition and structure of SP. Cutting edge technologies, viz. MTT assay, flow cytometry, western blot analysis, BCA protein assay, SDS-PAGE and gelatin zymography has been employed for analysis of their functional properties (Jiang and Guan 2009). Although the use of the seaweed-derived polysaccharides in food industry as thickening, gelling agents, and stable excipients for control release tablets are well established, the clinical use is still to gain ground. Manifold increase in the published findings on this aspect in recent time is evidence enough for the craze over this highly promising domain. Recently, Senni et al. (2011) have reviewed the advancement in therapeutic potential of marine polysaccharides. However, this report was not confined to seaweeds and dealt only with the tissue engineering applications. Also, Wijesekara et al. (2011) have published 
an overview of clinically crucial SP extracted from marine algae. Keeping with the hot trend and in an attempt to present a new perspective, the present review summarizes the up-to-date literature data and discusses the pharmaceutical potential of different SP extracted from brown, red and green seaweeds.

\section{Therapeutic potential of sulfated polysaccharides}

Researchers across the globe are waking up to the discovery that seaweed-derived bioactive products are a storehouse of healthy attributes. Recent times have seen a surge in interest to tap these unexploited marine sources to develop novel therapeutics. The SP of algal origin have exhibited miraculous biological properties. The common seaweeds, their SP and observed bioactivity spectra have been presented in Table 1 .

\section{Antioxidant}

Souza et al. (2012) isolated a SP by aqueous extraction from the red seaweed Gracilaria birdiae and observed that the slimy substance exhibits moderate antioxidant properties as measured by DPPH free-radical scavenging effect. Veena et al. (2007) evaluated the efficacy of fucoidan from edible seaweed Fucus vesiculosus in Wistar rats ( $5 \mathrm{mg} / \mathrm{kg}$ body wt.). Advocation of the SP enhanced the antioxidant status, thereby preventing membrane injury and averting stone formation. Barahona et al. (2011) evaluated the antioxidant capacity of sulfated galactans from red seaweed Gigartina skottsbergii and Schizymenia binderi, commercial carrageenans, and fucoidan from brown seaweed Lessonia vadosa by the oxygen radical absorbance capacity (ORAC) method. Fucoidan from $L$. vadosa and the sulfated galactan from $S$. binderi exhibited the highest antioxidant capacity. The antioxidant capacity was also evaluated by ABTS and hydroxyl radical scavenging assays. Corallina sertularioide, Dictyota cervicornis, Sargassum filipendula and Dictyopteris delicatula were studied and found to have SP having immense antioxidant potential in the form of total antioxidant, reducing power and ferrous ion chelating activities (Costa et al. 2010). Two SP fractions rich in galactose and xylose from Corallina officinalis demonstrated considerable antioxidant properties (Yang et al. 2011). Hu et al. (2010) isolated two sulfated rhamnose-rich polysaccharide fractions from Undaria pinnatifida and evaluated their antioxidant abilities in vitro. It was revealed that the SP possessed strong antioxidant properties. Ye et al. (2008) evaluated the antioxidant activities of SP from Sargassum pallidum by DPPH (2,2-diphenyl-1picrylhydrazyl)-free-radical scavenging assay and reported activity, though low at the tested concentration. Camara et al. (2011) extracted heterofucans from Canistrocarpus cervicornis by proteolytic digestion followed by sequential acetone precipitation. The SP exhibited total antioxidant capacity, low hydroxyl radical scavenging activity, good superoxide radical scavenging efficiency and excellent ferrous chelating ability. Devaki et al. (2009) studied the liver mitochondrial and microsomal fraction from rats to evaluate the antioxidative effect of oral gavaging with Ulva lactuca polysaccharide extract $(200 \mathrm{mg} / \mathrm{kg}$ body weight, daily for 21 days). Electron microscopy of rat liver tissue intoxicated with D-galactosamine revealed the swelling and loss of mitochondrial cristae. However, the rats pre-treated with the $\mathrm{SP}$ overcame the D-galactosamine challenge without significant abnormality of TCA, microsomal enzymes and mitochondria structural aberrations. These results suggested that the SP play crucial role in stabilizing the functional status of mitochondrial and microsomal membrane by prevention of the oxidative stress induced by D-galactosamine. Fucoidan was extracted from Laminaria japonica through anionexchange column chromatography and their antioxidant activities were investigated. Superoxide and hydroxyl radical scavenging activity, chelating ability and reducing power analysis showed that all fractions possessed considerable antioxidant activity (Wang et al. 2008). Gao et al. (2011) investigated the effects of fucoidan on improving learning and memory impairment in rats induced by infusion of betaamyloid peptide, $\mathrm{A} \beta(1-40)$ and its possible mechanisms. The results indicated that fucoidan could ameliorate $\mathrm{A} \beta$-induced cognitive disorders in neural maladies like Alzheimer's. The mechanisms appeared to regulate the cholinergic system (increasing the activity of choline acetyl transferase), reduce the oxidative stress (reduced malondialdehyde content in hippocampal tissue of brain) and inhibit the cell apoptosis (increase of $\mathrm{Bcl}-2 / \mathrm{Bax}$ ratio and a decrease of caspase-3 activity). Hong et al. (2011) investigated the protective effect of fucoidan on dimethylnitrosamine-induced liver fibrogenesis in rats. When administered $(100 \mathrm{mg} / \mathrm{kg}, 3$ times per week), fucoidan improved liver fibrosis by inhibiting the expression of transforming growth factor beta 1 [TGF- $\beta$ (1)]/Smad 3 and the tissue inhibitor of metalloproteinase 1 (TIMP-1), and increasing the expression of metalloproteinase-9 (MMP-9). Fucoidan also significantly decreased the accumulation of the extracellular matrix and collagen, confirming its anti-fibrotic effect. Costa et al. (2011b) obtained five sulfated heterofucans from S. filipendula by proteolytic digestion followed by sequential acetone precipitation, which displayed considerable antioxidant potential. Magalhaes et al. (2011) obtained six families of SP from seaweed $D$. delicatula employing above-mentioned protocols, followed by molecular sieving on Sephadex G-100. Some fractions of the heterofucans showed high ferrous ion chelating activity and some fractions showed reasonable reducing power, about $53.2 \%$ of the activity of vitamin $\mathrm{C}$. These results clearly indicate the beneficial 
Table 1 The studied seaweeds, their bioactive sulfated polysaccharides and therapeutic properties

\begin{tabular}{|c|c|c|c|}
\hline Biological properties & Seaweed & Sulfated polysaccharide & References \\
\hline Antioxidant & $\begin{array}{l}\text { Gracilaria birdiae (red) } \\
\text { Fucus vesiculosus (brown) } \\
\text { Gigartina skottsbergii (red) } \\
\text { Schizymenia binderi (red) } \\
\text { Lessonia vadosa (brown) } \\
\text { Dictyopteris delicatula (brown) } \\
\text { Sargassum filipendula (brown) } \\
\text { Laminaria japonica (brown) } \\
\text { Ulva lactuca (green) } \\
\text { Canistrocarpus cervicornis (brown) } \\
\text { Undaria pinnitafida (brown) } \\
\text { Corallina officinalis (red) } \\
\text { Corallina sertularioide (red) } \\
\text { Dictyota cervicornis (brown) } \\
\text { Sargassum filipendula (brown) } \\
\text { Dictyopteris delicatula (brown) }\end{array}$ & $\begin{array}{l}\text { Fucoidan } \\
\text { Galactan } \\
\text { Carrageenan } \\
\text { Rhamnan }\end{array}$ & $\begin{array}{l}\text { Souza et al. (2012) } \\
\text { Veena et al. (2007) } \\
\text { Barahona et al. (2011) } \\
\text { Magalhaes et al. (2011) } \\
\text { Costa et al. (2011a, b) } \\
\text { Wang et al. (2008) } \\
\text { Devaki et al. (2009) } \\
\text { Camara et al. (2011) } \\
\text { Hu et al. (2010) } \\
\text { Yang et al. (2011) } \\
\text { Costa et al. (2010) }\end{array}$ \\
\hline Antitumor & $\begin{array}{l}\text { Saccharina japonica (brown) } \\
\text { Undaria pinnatifida (brown) } \\
\text { Sargassum filipendula (brown) } \\
\text { Dictyopteris delicatula (brown) } \\
\text { Caulerpa prolifera (green) } \\
\text { Dictyota menstrualis (brown) } \\
\text { Monostroma nitidum (green) } \\
\text { Sargassum pallidum (brown) } \\
\text { Laminaria saccharina (brown) } \\
\text { Ecklonia cava (brown) } \\
\text { Sargassum hornery (brown) } \\
\text { Costaria costata (brown) } \\
\text { Sargassum filipendula (brown) } \\
\text { Dictyopteris delicatula (brown) } \\
\text { Champia feldmannii (red) } \\
\text { Ascophyllum nodosum (brown) } \\
\text { Cladosiphon okamuranus Tokida }\end{array}$ & $\begin{array}{l}\text { Galactofucan } \\
\text { Mannoglucuronofucan }\end{array}$ & $\begin{array}{l}\text { Vishchuk et al. (2011) } \\
\text { Costa et al. (2010) } \\
\text { Charles et al. (2007) } \\
\text { Ye et al. (2008) } \\
\text { Croci et al. (2011) } \\
\text { Ermakova et al. (2011) } \\
\text { Costa et al. (2011a, b) } \\
\text { Magalhaes et al. (2011) } \\
\text { Jin et al. (2010) } \\
\text { Lins et al. (2009) } \\
\text { Foley et al. (2011) } \\
\text { Haneji et al. (2005) }\end{array}$ \\
\hline Immunostimulatory & $\begin{array}{l}\text { Enteromorpha prolifera (green) } \\
\text { Champia feldmannii (red) } \\
\text { Fucus vesiculosus } \text { (brown) } \\
\text { Kappaphycus striatum (red) }\end{array}$ & $\begin{array}{l}\text { Fucoidan } \\
\kappa \text {-carrageenan } \\
\text { Oligosaccharides }\end{array}$ & $\begin{array}{l}\text { Kim et al. (2011, 2012) } \\
\text { Lins et al. (2009) } \\
\text { Kawashima et al. (2011) } \\
\text { Kima and Joo (2008) }\end{array}$ \\
\hline $\begin{array}{l}\text { Antiinflammation and } \\
\text { antinociceptive }\end{array}$ & $\begin{array}{l}\text { Solieria filiformis (red) } \\
\text { Gelidium crinale (red) } \\
\text { Sargassum hemiphyllum (brown) } \\
\text { Gracilaria cornea (red) } \\
\text { Gracilaria birdiae (red) } \\
\text { Laminaria saccharina (brown) } \\
\text { Lobophora variegate (brown) } \\
\text { Turbinaria ornata (brown) } \\
\text { Padina gymnospora (brown) }\end{array}$ & $\begin{array}{l}\text { Galactan } \\
\text { Mannoglucuronofucans } \\
\kappa \text {-carrageenan } \\
\text { Oligosaccharides }\end{array}$ & $\begin{array}{l}\text { de Araújo et al. (2011) } \\
\text { Farias et al. (2011) } \\
\text { de Sousa et al. (2011a) } \\
\text { Hwang et al. (2011) } \\
\text { Coura et al. (2011) } \\
\text { Croci et al. (2011) } \\
\text { Medeiros et al. (2008) } \\
\text { Ananthi et al. (2009) } \\
\text { Marques et al. (2012) } \\
\text { Jiang and Guan (2009) }\end{array}$ \\
\hline
\end{tabular}


Table 1 continued

\begin{tabular}{|c|c|c|c|}
\hline Biological properties & Seaweed & Sulfated polysaccharide & References \\
\hline $\begin{array}{l}\text { Anticoagulation and } \\
\text { antithrombosis) }\end{array}$ & $\begin{array}{l}\text { Ecklonia cava (brown) } \\
\text { Dictyota cervicornis (brown) } \\
\text { Caulerpa cupresoides (green) } \\
\text { Codium fragile (green) } \\
\text { Codium vermilara (green) } \\
\text { Monostroma latissimum (green) } \\
\text { Monostroma nitidum (green) } \\
\text { Canistrocarpus cervicornis (brown) } \\
\text { Dictyota menstrualis (brown) } \\
\text { Lomentaria catenata (red) } \\
\text { Laminaria saccharina (brown) }\end{array}$ & $\begin{array}{l}\text { Arabinogalactans } \\
\text { Rhamnan } \\
\text { Galactan }\end{array}$ & $\begin{array}{l}\text { Wijesinghe et al. (2011) } \\
\text { Costa et al. (2010) } \\
\text { Ciancia et al. (2007) } \\
\text { Li et al. (2011) } \\
\text { Mao et al. (2008) } \\
\text { Camara et al. (2011) } \\
\text { Albuquerque et al. (2004) } \\
\text { Pushpamali et al. (2008) } \\
\text { Croci et al. (2011) }\end{array}$ \\
\hline Lipid lowering & $\begin{array}{l}\text { Ulva lactuca (green) } \\
\text { Sargassum polycystum (brown) } \\
\text { Sargassum wightii (brown) } \\
\text { Laminaria japonica (brown) }\end{array}$ & Fucoidan & $\begin{array}{l}\text { Kim et al. (2010) } \\
\text { Sathivel et al. (2008) } \\
\text { Raghavendran et al. (2005) } \\
\text { Huang et al. (2010) }\end{array}$ \\
\hline Antiviral (Influenza, herpes, HIV) & $\begin{array}{l}\text { Gyrodinium impudium (red) } \\
\text { Nemalion helminthoides (red) } \\
\text { Gayralia oxysperma (green) } \\
\text { Sphaerococcus coronopifolius (red) } \\
\text { Boergeseniella thuyoides (red) } \\
\text { Sebdenia polydactyla (red) } \\
\text { Sphacelaria indica (brown) } \\
\text { Cystoseira indica (brown) } \\
\text { Grateloupia indica (red) } \\
\text { Laminaria angustata (brown) } \\
\text { Adenocystis utricularis (brown) } \\
\text { Scinaia hatei (red) }\end{array}$ & $\begin{array}{l}\text { Galactan } \\
\text { Mannans } \\
\text { Heterorhamnan } \\
\text { Xylomannan sulfate } \\
\text { Xylogalactofucan } \\
\text { Xylomannan }\end{array}$ & $\begin{array}{l}\text { Ghosh et al. (2009) } \\
\text { Kim et al. (2011, 2012) } \\
\text { Recalde et al. (2009) } \\
\text { Cassolato et al. (2008) } \\
\text { Bouhlal et al. (2011) } \\
\text { Bandyopadhyay et al. (2011) } \\
\text { Mandal et al. (2007) } \\
\text { Chattopadhyay et al. (2007) } \\
\text { Trinchero et al. (2009) } \\
\text { Mandal et al. (2008) }\end{array}$ \\
\hline $\begin{array}{l}\text { Antibacterial (ampicillin resistant } \\
\text { E. coli) Antiprotozoan } \\
\text { (cryptosporidiosis, malaria) }\end{array}$ & $\begin{array}{l}\text { Kappaphycus alvarezii (red) } \\
\text { Padina boergessenii (brown) } \\
\text { Undaria pinnatifida (brown) }\end{array}$ & Fucoidan & $\begin{array}{l}\text { Kumaran et al. (2010) } \\
\text { Maruyama et al. (2007) } \\
\text { Chen et al. (2009) }\end{array}$ \\
\hline Prevent hyperplasia & Brown seaweeds & Fucoidan & $\begin{array}{l}\text { Hlawaty et al. (2011) } \\
\text { Freguin-Bouilland et al. (2007) }\end{array}$ \\
\hline Cause gastrointestinal contraction & $\begin{array}{l}\text { Halymenia floresia (red) } \\
\text { Cladosiphon okamuranus Tokida (brown) }\end{array}$ & $\begin{array}{l}\text { Galactan } \\
\text { Fucoidan }\end{array}$ & $\begin{array}{l}\text { Graça et al. (2011) } \\
\text { Matsumoto et al. (2004) }\end{array}$ \\
\hline Regenerative and nano medicine & $\begin{array}{l}\text { Brown seaweeds } \\
\text { Ulva rigida (green) }\end{array}$ & $\begin{array}{l}\text { Fucoidan } \\
\text { Ulvan }\end{array}$ & $\begin{array}{l}\text { Sezer et al. (2008) } \\
\text { Murakami et al. (2010) } \\
\text { Nakamura et al. (2008) } \\
\text { Fukuta and Nakamura (2008) } \\
\text { Toskas et al. 2011) }\end{array}$ \\
\hline
\end{tabular}

effects of SP from seaweeds in antioxidant status of consumers.

\section{Antitumor}

Vishchuk et al. (2011) isolated fucoidans from brown seaweeds Saccharina japonica and U. pinnatifida and tested their antitumor activity against human breast cancer
T-47D and melanoma SK-MEL-28 cell lines. The highly branched partially acetylated sulfated galactofucan, built up of ( $1 \rightarrow 3)$ - $\alpha$-L-fucose residues from $S$. japonica and $U$. pinnatifida distinctly inhibited proliferation and colony formation in both breast cancer and melanoma cell lines in a dose-dependent manner. These results indicated that the fucoidan from the studied seaweeds may be a potential approach toward cancer treatment. After 72-h incubation of 
HeLa cell with SP $(0.01-2 \mathrm{mg} / \mathrm{ml})$, the proliferation was inhibited between 33.0 and $67.5 \%$ by S. filipendula; 31.4 and $65.7 \%$ by D. delicatula; 36.3 and $58.4 \%$ by Caulerpa prolifera, and 40.2 and $61.0 \%$ by Dictyota menstrualis. Costa et al. (2010) inferred that the antiproliferative efficacy of SP positively correlated with the sulfate content. In Sprague-Dawley rats fed with Monostroma nitidum diet, significant increase in UGT1A1 and UGT1A6 mRNA levels was found, indicating potential application in chemoprevention medicine (Charles et al. 2007). Ye et al. (2008) evaluated the antitumor activities of SP from $S$. pallidum by MTT [3-(4,5-dimethylthiazol-2-yl)-2,5-diphenyltetrazolium bromide] assay, which showed a significantly high antitumor activity against the human hepatocellular carcinoma (HepG2), human lung adenocarcinoma epithelial (A549) and human gastric carcinoma (MGC-803) cells. Croci et al. (2011) explored the possible antitumor activities of SP from the brown seaweed Laminaria saccharina. The incorporation of the parent SP and the sulfated fucans into Matrigel plugs containing melanoma cells induced a significant reduction in hemoglobin content as well as the frequency of tumor-associated blood vessels. Also, these two SP administrations resulted in a significant reduction of tumor growth when inoculated into mice. The sulfated fucan fraction markedly inhibited breast cancer cell adhesion to human platelet-coated surfaces. Ermakova et al. (2011) showed that fucoidans from brown algae Eclonia cava, Sargassum hornery and Costaria costata play an inhibitory role in colony formation in human melanoma and colon cancer cells. Costa et al. (2011b) observed antiproliferative activity of fucan from $S$. filipendula against HeLa cells by MTT test. The heterofucan was extracted from the brown seaweed by proteolytic digestion followed by sequential acetone precipitation. This SP showed antiproliferative activity on Hela cells and induced apoptosis by mitochondrial release of apoptosis-inducing factor (AIF) into cytosol. In addition, it decreased the expression of anti-apoptotic protein Bcl-2 and increased expression of apoptogenic protein Bax. Magalhaes et al. (2011) obtained six families of SP from seaweed $D$. delicatula by proteolytic digestion, followed by acetone fractionation and molecular sieving on Sephadex G-100. A fraction of the heterofucan showed high antiproliferative activity inhibiting almost $100 \%$ of HeLa cell proliferation. Jin et al. (2010) investigated the effects of fucoidan on the apoptosis of human promyeloid leukemic cells and fucoidan-mediated signaling pathways. Fucoidan induced apoptosis of human promyelocytic leukemia (HL-60), human promyelocytic (NB4) and THP1 (human acute monocytic leukemia) cell line. Fucoidan treatment of HL-60 cells induced activation of caspases 8, 9 , and 3, the cleavage of Bid, and altered mitochondrial membrane permeability. Buthionine- $[R, S]$-sulfoximine rendered HL-60 cells more sensitive to fucoidan. It was concluded that the activation of MEKK1, MEK1, ERK1/2 and JNK, depletion of glutathione and production of NO are important mediators in fucoidan-induced apoptosis of human leukemic cells. Lins et al. (2009) investigated the in vitro and in vivo antitumor properties of a SP isolated from the seaweed $C$. feldmannii. The SP did not show any significant in vitro cytotoxicity at the experimental dose, but showed in vivo antitumor effect. The inhibition rates of sarcoma 180 tumor development were 48.62 and $48.16 \%$ at the doses of 10 and $25 \mathrm{mg} / \mathrm{kg}$, respectively. It also increased the response elicited by anti-cancer drug, 5-fluorouracil (5-FU) from 48.66 to $68.32 \%$. Though liver and kidney were moderately affected, the enzymatic activity of alanine aminotransferase or urea/creatinine levels was not disturbed. Leucopenia associated with 5-fluorouracil treatment was prevented when the chemotherapeutic was administered along with SP. An unfractionated fucoidan was extracted from the brown alga Ascophyllum nodosum and its effect on the apoptosis of human HCT116 colon carcinoma cells was studied and the signaling pathways involved were investigated. Fucoidan decreased cell viability and induced apoptosis of the carcinoma cells, through activation of caspases 9 and 3 and the cleavage of PARP (Foley et al. 2011). Haneji et al. (2005) examined the effect of fucoidan from the brown seaweed Cladosiphon okamuranus Tokida against an incurable form of cancer, the adult T-cell leukemia (ATL). It was observed that fucoidan inhibited the growth of peripheral blood mononuclear cells of ATL patients and caused apoptosis of HTLV-1-infected T-cell lines through a cascade of down regulations. In vivo treatment of the cancer transplanted in mice also showed partial inhibition of the tumors. Now that, cancer has assumed an epidemic proportion and the treatment scenario is still bleak, the SP from the marine weeds hold the promise for novel anticancer formulae.

\section{Immunostimulatory}

Water-soluble SP extracted from Enteromorpha prolifera and fractionated using ion-exchange chromatography was investigated to determine their in vitro and in vivo immunomodulatory activities. Some fractions stimulated a macrophage cell line Raw 264.7 inducing considerable nitric oxide (NO) and various cytokine production via upregulated mRNA expression. The in vivo experiment results showed increase in IFN- $\gamma$ and IL-2 secretions, suggesting that the SP is a strong immunostimulator. It is implied that the SP can activate $\mathrm{T}$ cells by up-regulating Th-1 response (Kim et al. 2011). Lins et al. (2009) demonstrated that SP extracted from $C$. feldmannii is an immunomodulatory agent, evident from the increase in the production of specific antibodies. Kawashima et al. (2011) 
demonstrated that fucoidan enhances the probiotic effects of lactic acid bacteria on immune functions. In vitro test results showed that fucoidan amplified interferon (IFN)- $\gamma$ production mediated by IL-12 production from Peyer's patch and spleen cells in response to a strain of LAB, Tetragenococcus halophilus KK221. In vivo study showed that Th1/Th2 immunobalance was significantly improved by oral administration of both fucoidan and KK221 to ovalbumin-immunized mice. Kima and Joo (2008) observed that fucoidan from $F$. vesiculosus shows immunostimulating and maturing effects on dendritic cells (DCs) via a pathway involving nuclear factor- $\kappa \mathrm{B}(\mathrm{NF}-\kappa \mathrm{B}) . \kappa-$ Carrageenan oligosaccharides from red algae Kappaphycus striatum have immunomodulation effects on S180 tumorbearing mice. The sulfated derivative $(200 \mu \mathrm{g} / \mathrm{g} / \mathrm{day})$ showed an increase in natural killer cells (NK cells) up to $76.1 \%$. It suggested that chemical modification (especially sulfation) of carrageenan oligosaccharides can enhance their antitumor effect and boost their antitumor immunity. Yuan et al. (2011) reported not only the capacity of SP to elicit cellular immunity but also the importance of chemical modification of the parent polysaccharide.

\section{Anti-inflammation/antinociception/inhibition of pulmonary fibrosis}

de Araújo et al. (2011) studied the antiinflammatory and antinociception (less sensitivity to painful stimulus) properties of seaweed Solieria filiformis in vivo. Male Swiss mice pre-treated with the SP, on receiving an injection of $0.8 \%$ acetic acid, $1 \%$ formalin or $30 \mathrm{~min}$ prior to a thermal stimulus, showed significantly reduced number of writhes. It showed antinociceptive action through a peripheral mechanism; however, did not show any significant anti-inflammatory effect. The SP from the brown seaweed Spatoglossum schroederi was assayed for the antinociceptive effect on Swiss mice. The SP purified by anion-exchange chromatography inhibited both phases of the formalin test. In the first phase the maximum $45 \%$ reduction in paw licking was observed. This inhibitory effect suggested a mixed mechanism similar to morphine, which was not confirmed in the hot-plate test. It was concluded that the pronounced antinociceptive effect of SP could be developed as a new source of analgesic drugs (Farias et al. 2011). The SP galactan extracted from the red marine alga Gelidium crinale was purified by ion-exchange chromatography and tested by intravenous route in rodent experimental models of inflammation and nociception. The anti-inflammatory activity was evaluated in the model of rat paw edema induced by different inflammatory stimuli. Antinociceptive effect was assessed in models of nociception/hyperalgesia elicited by chemical (formalin test), thermal (hot plate), and mechanical (von Frey) stimuli in mice. It was observed that SP inhibited the time course of dextran-induced paw edema and showed a maximal effect at $1 \mathrm{mg} / \mathrm{kg}(42 \%)$. At the highest dose, the SP also inhibited the paw edema induced by histamine $(49 \%)$ and phospholipase A(2) (44\%). The galactan inhibited both neurogenic and inflammatory phases of the formalin test and the treatment was well tolerated by the test animals (de Sousa et al. 2011a). Hwang et al. (2011) explored SP from brown seaweed Sargassum hemiphyllum for possible antiinflammatory effect. The SP was administered against the mouse macrophage cell line (RAW 264.7) activated by lipopolysaccharide (LPS). The secretion profiles of proinflammatory cytokines, including IL- $1 \beta$, IL- 6 , TNF- $\alpha$, and $\mathrm{NO}$, were found significantly to be reduced in $1-5 \mathrm{mg} / \mathrm{ml}$ dose ranges of SP treatments. RT-PCR analysis suggested that the SP inhibits the LPS-triggered mRNA expressions of IL- $\beta$, iNOS and COX-2 in a dose-dependent manner. It was concluded that the anti-inflammatory properties of SP may be attributed to the down-regulation of NF- $\kappa \mathrm{B}$ in nucleus. Coura et al. (2011) evaluated the effects of SP from the red seaweed Gracilaria cornea in nociceptive and inflammatory mice models. At all tested doses, the SP significantly reduced nociceptive responses, as measured by the number of writhes. In a formalin test, the SP significantly reduced licking time in both phases of the test at a dose of $27 \mathrm{mg} / \mathrm{kg}$. In a hot-plate test, the antinociceptive effect was observed only in animals treated with $27 \mathrm{mg} / \mathrm{kg}$ of SP, suggesting that the analgesic effect occurs through a central action mechanism at the highest dose. The lower doses of SP (3 and $9 \mathrm{mg} / \mathrm{kg}$ ) caused only a slight reduction in neutrophil migration in the rat peritoneal cavity but significantly inhibited paw edema induced by carrageenan, especially at $3 \mathrm{~h}$ after treatment. Reduction in edema was confirmed by myeloperoxidase activity in the affected paw tissue. After 14 consecutive days of intraperitoneal administration of the SP $(9 \mathrm{mg} / \mathrm{kg})$, the biochemical, hematological and histopathological evaluations of the internal organs are performed and no systemic damage was found. de Sousa et al. (2011b) investigated the involvement of the hemoxygenase-1 (HO-1) pathway in the antiinflammatory action of a SP from the red seaweed $G$. birdiae. The SP was administered at various concentrations to Wistar rats and observed that at $10 \mathrm{mg} / \mathrm{kg}$ concentration, it exerted an anti-inflammatory effect. A remarkable decrease in leukocytes in the peritoneal cavity was also observed. The SP also reduced the paw edema induced by carrageenan and inhibited the paw edema induced by dextran in the first half-hour. The $O$-sulfated mannoglucuronofucans and sulfated fucan fractions from the brown seaweed $L$. saccharina were evaluated for possible treatment of inflammation in vivo. Both types of SP exhibited inhibition of leukocyte rush into the sites of inflammation in the murine models (Croci et al. 2011). 
Medeiros et al. (2008) extracted a sulfated heterofucan from the brown seaweed Lobophora variegata by proteolytic digestion, followed by acetone fractionation, molecular sieving, and ion-exchange chromatography. The fucoidan revealed that it inhibits leukocyte migration to the inflammation site. Ear swelling caused by croton oil was also inhibited when sulfated polysaccharides from $F$. vesiculosus and L. variegata were used. Ananthi et al. (2009) investigated the anti-inflammatory effect of crude SP from brown alga Turbinaria ornata against carrageenan-induced paw edema in rats and vascular permeability in mice. Oral administration of SP reduced the paw edema and showed inhibitory effect on vascular permeability considerably, in a dose-dependent manner. SP extracted from brown algae Padina gymnospora showed efficacy in reducing leukocyte influx into the peritoneal cavity in mice at $10 \mathrm{mg} / \mathrm{kg}$ body weight, causing a decrease of $60 \%$, without any cytotoxicity (Marques et al. 2012). Idiopathic pulmonary fibrosis is a pathological condition characterized by accumulation of excess fibroblasts, deposition of collagen and inflammation in lungs. The pro-fibrogenic cytokine transforming growth factor-beta 1 (TGF-beta1) has attracted much attention for its potential role in the etiology of this serious lung injury. MS80, a new kind of sulfated oligosaccharide extracted from seaweed, inhibits TGF-beta1-induced pulmonary fibrosis in vitro and bleomycin-induced pulmonary fibrosis in vivo. The oligosaccharide competitively inhibited heparin/HS-TGF-betal interaction through its high binding affinity for TGF-beta1, also arrested human embryo pulmonary fibroblast (HEPF) cell proliferation and collagen deposition. MS80 proved to be a potent suppressor of bleomycin-induced rat pulmonary fibrosis in vivo (Jiang and Guan 2009). Du et al. (2010) reported that efficacy of MS80 lies in targeting the CD40 signal pathway by blocking RIP2. The precise mechanism of functionality is not clear; nevertheless, the sulfated polysaccharides studied above promise therapeutic potential in inflammatory disorders.

\section{Anticoagulation}

Batteries of assays for assessment of anticoagulation properties of SP from seaweeds have been conducted in recent times. Tests ranging from activated partial thromboplastin time (APTT), thrombin time (TT), prothrombin time (PT), antithrombin to anticoagulation factor Xa activities have been performed and compared with heparin. Wijesinghe et al. (2011) purified a SP from brown seaweed Ecklonia cava and investigated its anticoagulant activity in vitro and in vivo. It extended the coagulation time in Wistar rats in a dose- and time-dependent manner. Costa et al. (2010) evaluated in vitro anticoagulant activities of marine algae SP by APTT test. D. cervicornis SP prolonged the coagulation time, only 1.4-fold lesser than Clexane ${ }^{\circledR}$, a low molecular weight commercial heparin. In the prothrombin time (PT) test, which evaluates the extrinsic coagulation pathway, Caulerpa cupresoides showed aggression. Codium fragile and Codium vermilara water-soluble sulfated arabinogalactans prevented coagulation, but they induced platelet aggregation. It was observed that anticoagulant activity was higher in SP samples with higher sulfate content. In this regard, C. vermilara proved to be superior with a higher degree of sulfation and arabinose content (Ciancia et al. 2007). The hot water extract of green alga Monostroma latissimum gives a sulfated rhamnan polysaccharide with an anticoagulant activity. The anticoagulant activity as evaluated by assays of the APTT and thrombin time promises that it can be a potential source of anticoagulant ( $\mathrm{Li}$ et al. 2011). Mao et al. (2008) isolated two sulfated, rhamnose-containing polysaccharides from marine green algae $M$. nitidum and evaluated their anticoagulant activities. The results showed that both the SP possess high anticoagulant activities, and were potent thrombin inhibitors mediated by heparin cofactor II. They also hastened thrombin and coagulation factor Xa inhibition by potentiating antithrombin III. Camara et al. (2011) extracted sulfated heterofucans from $C$. cervicornis which prolonged APTT. Four sulfated polysaccharides doubled APTT with only $0.1 \mathrm{mg} / \mathrm{ml}$ of plasma, only 1.25 -fold less than Clexane ${ }^{\circledR}$. Albuquerque et al. (2004) extracted heterofucans from the brown seaweed $D$. menstrualis by proteolytic digestion, followed by sequential acetone precipitation. The anticoagulant activities of these heterofucans were determined by APTT test. A fucan fraction $(20 \mathrm{~g} / \mathrm{ml})$ demonstrated significant anticoagulant activity, about 4.88 -fold lesser than Clexane ${ }^{\circledR}(4.1 \mathrm{~g} / \mathrm{ml})$. Pushpamali et al. (2008) isolated a highly sulfated (21.76\%), 100-500 kDa molecular weight galactan anticoagulant from microbial-fermented freeze-dried red algae Lomentaria catenata. It demonstrated that the anticoagulant compound showed better efficacy than heparin and prolonged activity toward APTT and PT assays. Croci et al. (2011) studied that the SP from the brown seaweed $L$. saccharina shows promising activity on thrombosis. Fernández et al. (2012) studied the anticoagulation efficacy of sulfated $\beta$-D-mannan extracted from green seaweed $C$. vermilara and reported that higher sulfate content leads to more pronounced effect. Fucoidan has been proposed as a potential substitute of the anticoagulant heparin, with added merits. Unlike mammalian mucosa-derived heparin, fucoidan is extracted from plants, so less likely to contain infectious agents, such as viruses or prions (Boisson-Vidal et al. 1995). The current findings promise a host of possible candidates for natural anticoagulant preparation. 
Lipid lowering

Fucoidan has been reported to affect the development of adipocytes. To elucidate the role of fucoidan in adipogenesis, its inhibitory effect on adipocyte differentiation via mitogen-activated protein kinase (MAPK) signaling pathway in 3T3-L1 preadipocytes was studied. Fucoidan treatment inhibited the adipocyte differentiation, evidenced by decreased lipid accumulation and down-regulation of adipocyte markers. Also, it inhibited the expression of adipogenic transcription factors, $\alpha(\mathrm{C} / \mathrm{EBP} \alpha), \gamma(\operatorname{PPAR} \gamma)$ and AP2, crucial for adipocyte development (Kim et al. 2010). Sathivel et al. (2008) evaluated the anti-peroxidative and anti-hyperlipidemic property of $U$. lactuca polysaccharide extract against D-galactosamine $(500 \mathrm{mg} / \mathrm{kg}$ body weight)induced anomaly in rat. D-Galactosamine-intoxicated rats showed significant liver damage with acute aberration in serum lipid profile, hepatic protein thiols, deposits of lipid droplets and abnormal appearance of mitochondria. Rats pretreated with ulvan $(30 \mathrm{mg} / \mathrm{kg}$ body weight/day/for 21 days) showed a significant inhibition against abnormality induced by D-galactosamine. The effect of Sargassum polycystum crude SP extract on lipid metabolism was examined against acetaminophen-induced hyperlipidemia in experimental rats. The prior oral administration of $S$. polycystum $(200 \mathrm{mg} / \mathrm{kg}$ body wt./day for a period of 15 days) crude SP extract showed considerable prevention in the severe disturbances of lipid profile and metabolizing enzymes (serum lecithin cholesterol acyl transferase and hepatic triglyceride lipase) triggered by acetaminophen. Liver histology also supported their protective nature against fatty changes induced during acetaminophen intoxication (Raghavendran et al. 2005). Josephine et al. (2007) studied the possible capacity of SP in normalizing hyperlipidemia induced by the immunosuppressant drug cyclosporine A ( $25 \mathrm{mg} / \mathrm{kg}$ body weight, orally for 21 days) in Wistar rat kidney. As a side effect of the drug, lipid profile showed fluctuation resulting in nephrotoxicity manifested by the enhanced urinary excretion of urea, uric acid and creatinine. The SP-treated groups $(5 \mathrm{mg} / \mathrm{kg}$ body weight, subcutaneously) showed a normalized lipid profile and lipid metabolizing enzymes. Moreover, this group of rats showed a normal concentration of urinary constituents. Huang et al. (2010) investigated the effect of fucoidan from $L$. japonica on hyperlipidemic rats. The SP reduced the concentration of serum total cholesterol, triglyceride and low-density lipoprotein cholesterol and increased the concentration of high-density lipoprotein cholesterol of the studied rats. The activities of lipoprotein lipase, hepatic lipoprotein and lecithin cholesterol acyltransferase were also enhanced. Above findings corroborate that the SP from seaweeds are ideal option for effective abatement of the lipid abnormalities.
Antiviral

Many viruses display affinity for cell surface heparan sulfate proteoglycans playing crucial role in virus entry. This raises the possibility of the application of SP in antiviral therapy (Ghosh et al. 2009). Kim et al. (2012) purified a $\mathrm{SP}, \mathrm{p}-\mathrm{KG} 03$, from the red marine microalga, Gyrodinium impudium. The galactan conjugated to uronic acid and sulfated groups had showed inhibition of encephalomyocarditis virus. The inhibitory activity of the SP against influenza virus was examined. The results of a cytopathic effect reduction assay using MDCK cells demonstrated that p-KG03 exhibited the $50 \%$ effective concentration (EC50) values of $0.19-0.48 \mu \mathrm{g} / \mathrm{ml}$ against influenza type A virus infection. The antiviral activity of p-KG03 was deduced to be directly associated with its interaction with viral particles, interfering with its adsorption and internalization into host cell. It was expected to be a candidate for antiviral drug development. The soluble fractions of a sulfated, $(1 \rightarrow 3)$-linked $\alpha$-D-mannans obtained by hot water extraction from Nemalion helminthoides showed appreciable antiherpetic activity (Recalde et al. 2009). A homogeneous branched sulfated heterorhamnan was obtained by aqueous extraction, followed by ultrafiltration from the green seaweed Gayralia oxysperma which exerted high specific activity against herpes simplex virus (HSV-1) (Cassolato et al. 2008). Treatment of human immunodeficiency virus type 1 (HIV-1), the dreaded etiological agent of AIDS poses tough challenges. The limitations encountered in therapeutic strategy are toxicity, resistance and high costs. Water-soluble sulfated galactans isolated from two red algae Sphaerococcus coronopifolius (Gigartinales, Sphaerococcaceae) and Boergeseniella thuyoides (Ceramiales, Rhodomelaceae) inhibited in vitro replication of the human immunodeficiency virus (HIV) at $12.5 \mu \mathrm{g} / \mathrm{ml}$. In addition, the studied polysaccharides were capable of inhibiting the in vitro replication of HSV-1 on Vero cells. The adsorption step of HSV-1 to the host cell seemed to be the specific target for the SP action. While for HIV-1, these results suggest a direct inhibitory effect on HIV-1 replication by controlling the appearance of the new generations of virus and potential virucidal effect (Bouhlal et al. 2011). Ghosh et al. (2009) studied that xylomannan sulfate and its sulfated derivatives purified from Sebdenia polydactyla showed strong activity against HSV-1. The IC50 values were in the range $0.35-2.8 \mu \mathrm{g} / \mathrm{ml}$ and they did not exert cytotoxicity at concentrations up to $1,000 \mu \mathrm{g} / \mathrm{ml}$. Many xylogalactofucan- and alginic acid-containing fractions from marine alga Sphacelaria indica showed antiherpetic activity. The IC50 values of their chemically sulfated derivatives against HSV-1 were in the range of $0.6-10 \mu \mathrm{g} /$ $\mathrm{ml}$ and they lacked cytotoxicity at concentrations up to $200 \mu \mathrm{g} / \mathrm{ml}$ (Bandyopadhyay et al. 2011). Sulfated fucan-

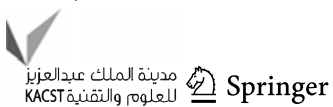


containing fractions isolated from the brown seaweed Cystoseira indica showed potent antiviral activity against HSV-1 and 2 HSV-2 without cytotoxicity for Vero cell cultures. Chemical, chromatographic and spectroscopic methods showed that the anti-herpetic activity of the SP is by inhibition of the virus adsorption (Mandal et al. 2007). Chattopadhyay et al. (2007) analyzed the SP fractions isolated from crude water extract of Grateloupia indica and showed their potent anti-HSV activity. The SP, xylogalactofucan fractions extracted from Laminaria angustata, after addition of sulfate groups showed enhanced capability to inhibit HSV-1. The IC50 values of these fractions against HSV-1 were in the range of $0.2-25 \mu \mathrm{g} / \mathrm{ml}$ and they lacked cytotoxicity at concentrations up to $1,000 \mu \mathrm{g} / \mathrm{ml}$ (Saha et al. 2012). SP fractions from brown seaweed $A d$ enocystis utricularis were analyzed for their in vitro antiHIV-1 activity. Two of the five studied fractions showed potent anti-HIV-1 activity both against wild type and drugresistant HIV-1 strains, mediated by blockade of early events of viral replication (Trinchero et al. 2009). The antiviral activity was dependent on the sulfate contents of the polysaccharides. Kazłowski et al. (2012) conducted both in vitro and in vivo studies on Japanese encephalitis virus prevention property of novel SP from Gracilaria sp. and M. nitidum. During in vitro studies performed by MTT or plaque assays, low-degree-polymerization SP showed a remarkably high positive effect on survivability in JEVinfected $\mathrm{C} 3 \mathrm{H} / \mathrm{HeN}$ mice. The in vivo antiviral activity was assumed to be a resultant of better absorption of low-DP SP than undigested PS. The results support the feasibility of antiviral drug development from various SP and their derivatives.

\section{Antibacterial and antiprotozoan}

Kumaran et al. (2010) studied that SP extracted from red alga Kappaphycus alvarezii and brown alga Padina boergessenii exert promising inhibitory response against antimicrobial-resistant Escherichia coli strains and, in particular, the inhibitory response of ampicillin-resistant $E$. coli, isolated from local fish markets and seafood processing plants. Maruyama et al. (2007) investigated the effects of fucoidan isolated from the sporophyll of $U$. pinnatifida on the Cryptosporidium parvum adhesion to the cultured human intestinal cells and its infection in neonatal mice. The $C$. parvum adhesion to human intestinal 407 cells was significantly suppressed by a low dose $(1 \mathrm{mg} / \mathrm{ml})$ of fucoidan $(1 \mu \mathrm{g} / \mathrm{ml})$. The results of the in vivo experiments revealed that $C$. parvum oocysts in the fucoidantreated mice was reduced to nearly one-fifth of the oocysts number treated with phosphate buffered saline. It was concluded that fucoidan might inhibit cryptosporidiosis through the direct binding of fucoidan to the C. parvum- derived functional mediators in the intestinal epithelial cells in neonatal mice. Chen et al. (2009) investigated the inhibitory effects of fucoidan from the edible brown seaweed $U$. pinnatifida, on the growth of Plasmodium parasites. The antimalarial activity of fucoidan was assessed against the cultured Plasmodium falciparum parasites in vitro and on Plasmodium berghei-infected mice in vivo. Fucoidan significantly inhibited the invasion of erythrocytes by $P$. falciparum merozoites. Its $50 \%$ inhibition concentration was similar to those for the chloroquinesensitive $P$. falciparum 3D7 strain and the chloroquineresistant K1 strain. Four-day suppressive testing in $P$. berghei-infected mice with fucoidan resulted in a $37 \%$ suppressive effect versus the control group and a delay in death associated with anemia.

\section{Prevent hyperplasia}

Hlawaty et al. (2011) investigated the therapeutic potential of low molecular weight fucoidan on vascular smooth muscle cell and human vascular endothelial cell proliferation and migration in vitro and in vivo. Sprague-Dawley rats with induced thoracic aorta injury were treated with SP ( $5 \mathrm{mg} / \mathrm{kg} / \mathrm{day}$ ) for 14 days. Results showed that SP prevented intimal hyperplasia in rat thoracic aorta. In situ zymography showed that the activity of matrix metalloproteinase (MMP)-2 in the neo-intima is significantly reduced. Fucoidans have been shown to mobilize bone marrow-derived progenitor cells via stimulation of stromalderived factor (SDF)-1 release. Mobilized progenitor cells have been suggested to repair intimal lesions after immunemediated endothelial injury and thus prevent intimal proliferation. Freguin-Bouilland et al. (2007) evaluated the therapeutic effect of these SP, in Brown Norway and Lewis rat aortic allograft model of transplant arteriosclerosis. The recipient rats were treated with $\mathrm{SP}(5 \mathrm{mg} / \mathrm{kg} / \mathrm{day})$ for 30 days. In contrast to untreated aortic allografts, the SPtreated allografts showed significantly less intimal proliferation. The SP treatment stimulated allograft reendothelialization, as evidenced by strong intimal endothelial nitric oxide synthase antibody and CD31 signals.

\section{Gastrointestinal functions}

Graça et al. (2011) showed that a sulfated galactan isolated from red algae Halymenia floresia has promising effects on gastrointestinal (GI) motor functions mediated by voltagegated $\mathrm{Ca}^{2+}$ channels. So, it is suggested that the SP can be useful when gastrointestinal contraction is necessary during motility-related disorders. Inflammatory bowel disease caused by enteric pathogens is a severe form of gastric disease characterized by excess production of proinflammatory cytokine IL-6. Fucoidan derived from brown algae 
C. okamuranus Tokida imparts LPS tolerance and prevents the expression of IL- 6 mRNA as evidenced by in vitro and in vivo tests (Matsumoto et al. 2004).

In regenerative and nano medicine

Sezer et al. (2008) prepared a fucoidan-chitosan hydrogel by swelling the polymers in acidic solution and investigated its dermal burn treatment efficiency. Dermal burns were inflicted on male New Zealand white rabbits and the prepared hydrogel was applied on the wounds. Histopathological evaluation of the biopsy samples was done at intervals. No edema was seen in tested groups after 3-day treatment and fibroplasia and scar were fixed after 7-day treatment. The best regeneration on dermal papillary formation and the fastest closure of the wounds were observed in fucoidan-chitosan hydrogels after 14-day treatment. Murakami et al. (2010) developed a hydrogel sheet by blending alginate, chitosan and fucoidan, for rapid wound healing. The hydrogel absorbed Dulbecco's minimal essential medium (DMEM) and fluid absorption became constant within $18 \mathrm{~h}$. On application, this hydrogel is expected to act as tissue adhesive and heal the wound in a moist milieu. Histological examination showed the advanced granulation tissue and capillary formation in the healing-impaired wounds treated with the hydrogel on day 7. Nakamura et al. (2008) reported that a chitosan/fucoidan complex-hydrogel enhanced the half life of fibroblast growth factor (FGF-2) by shielding it against denaturants as heat and proteolysis. Subcutaneous injection of the FGF-2-containing complex-hydrogel into the back of mice showed controlled release of bioactive protein. Slow diffusion of the growth factor induced neovascularization and fibrous tissue formation near the site of injection after 1 week. The complex-hydrogel was biodegraded after 4 weeks after supplying adequate amount of the angiogenic agents for protection of the ischemic heart. Fukuta and Nakamura (2008) reported that fucoidan and its oligosaccharides have the ability to stimulate production of hepatocyte growth factor (HGF) by induction during translation. So, it is believed that fucoidan may protect tissues and organs by mechanisms involving HGF.

Toskas et al. (2011) evaluated the nanofiber ability of an ulvan-rich extract from the alga Ulva rigida. Ulvanbased uniform, crystalline nanofibers of diameter $84 \mathrm{~nm}$ were produced by blending them with poly(vinyl alcohol) (PVA). The interesting biological and physicochemical properties of the nanofibers can lead to new biomedical applications such as drug release systems. Taken together, these findings indicate that the SP can revolutionize regenerative and nanomedicine, if exploited properly.

\section{Bottlenecks encountered}

Extraction yield differs with respect to species, period and season of seaweed harvest (Robic et al. 2009). The SP are extracted from the seaweed biomass by many methods which influence their amount and chemical composition. The fucans of brown algae are highly complex and heterogeneous in structure, rendering their study difficult. Fonseca et al. (2008) compared the galactans from two species of red algae having same structure and size but slight variation in sulfation. Due to the variation in sulfate content, the two SP differed in their anticoagulant and venous antithrombotic activities. From the results it was concluded that slight differences in the proportions of sulfated residues in the galactan chain may be critical for the interaction between proteases, inhibitors and activators of the coagulation system. Also, the variations pose challenges in developing therapeutics. Furthermore, the high molecular weights of SPs pose issue in bio-availability (Jiao et al. 2011).

\section{Structure-function correlation of SP}

It is important to understand the biochemical and molecular mechanism of therapeutic actions of SP, in order to develop effective drugs. The monomeric constituents, molecular size, sulfation site, specific structural motif, degree of branching determination are vital for reproducibility of result. Pomin (2009) has reported that the anticoagulant action of SP lies in its ability to inhibit plasma proteases via allosteric changes. The stereospecificities of the carbohydrate-protein complexes hinge on the number of residues in the repeating units, sulfation pattern, anomeric configuration, glycosidic linkage position and molecular mass. Also, the heterogeneities, such as acetylation, methylation and pyruvilation contribute in eliciting variations in functionality (Bilan et al. 2007). A single structural change has been traced to result considerable qualitative difference in results. Pomin and Mourao (2008) reported that preparation of oligosaccharides with welldefined chemical structures from sulfated fucan helps in the studies of carbohydrate-protein interaction. Fonseca et al. (2008) reported that algal sulfated galactans have a procoagulant effect along with the serpin-dependent anticoagulant activity. The procoagulant effect depends on the sulfation pattern of the SP. Slight differences in the proportions and/or distribution of sulfated residues along the galactan chain is critical for the interaction between proteases, inhibitors, and activators of the coagulation system, resulting in a distinct pattern in anti- and procoagulant activities. Identification of structural attributes of SP vital for their biological activities has been limited by their 
heterogeneous structures. Alasalvar et al. (2010) reported the strong correlation between structure of SP and their antioxidant potency. The monomeric constitution, degree of sulfation and their position, type of glycosidic linkage were held chief determining factors for variation in activity. High sulfate content and low molecular size were studied to exert stronger radical scavenging activities. Frenette and Weiss (2000) determined that sulfation is critical for efficacy of fucoidan in hematopoietic progenitor activity. The desulfated fucoidan failed to promote angiogenesis in vitro or to induce immature $\mathrm{CD} 34+$ cell mobilization in vivo. Fucoidan inhibits the human complement system mediated through interactions with certain proteins belonging to the classical pathway, particularly the protein C4. NMR spectra showed that the branched fucoidan oligosaccharides display a better anticomplementary activity compared to linear structures. Spectroscopy and molecular modeling of fucoidan oligosaccharides indicated that the presence of side chains reduces the flexibility of the backbone, mimicking a conformation recognized by the protein C4 (Clement et al. 2010). Leiro et al. (2007) observed that immunostimulatory activity of ulvan-like SP extracted from $U$. rigida was decreased significantly after desulfation of the SP, suggesting the importance of the functional group in eliciting immune response. To tackle the problem of heterogeneity of algal SP, a new approach has been established. The information obtained from studies of invertebrate SP that have a regular structure can be used to deduce the functionally of algal SP (Jiao et al. 2011).

\section{Maximization of the extraction and improvement in bioavailability}

Aqueous (Ghosh et al. 2009) and acetone extraction (Marques et al. 2012) are the most prevalent techniques in SP production from seaweeds. Due to the variations in active growth parameters and extraction conditions, every new SP purified is a unique compound with signature structural features, promising a potential new drug. Rodriguez-Jasso et al. (2011) extracted fucoidan from brown seaweed $F$. vesiculosus by microwave-assisted extraction. Extraction at $120 \mathrm{psi}, 1 \mathrm{~min}$, using $1 \mathrm{~g} / 25 \mathrm{ml}$ water proved optimum condition for maximum fucoidan recovery. It was concluded that pressure, extraction time and alga/water ratio affected the SP yield (Rodriguez-Jasso et al. 2011). Supercritical $\mathrm{CO}_{2}$ extraction, ultrasonic-aid extraction and membrane separation technology may be applied to harvest SP from the seaweeds. Short extraction times, and non-corrosive solvents, cost effective an environmentally benign technique are required for maximum yield. Acid hydrolysis of high molecular weight fucans into low molecular weight compounds facilitates their structural investigation. Further, the low molecular weight fucoidans can be obtained by fucoidanase (E.C.3.2.1.44) treatment. This enzyme sourced from hepatopancreas of invertebrates, marine bacteria and fungi has an added advantage of hydrolyzing the SP without messing with its side substitute groups (Qianqian et al. 2011). Endolytic enzymes, such as ulvan lyases isolated from the flavobacteria Persicivirga ulvanivorans cleave the glycosidic bond between the sulfated rhamnose and a glucuronic or iduronic acid in the ulvans (Collen et al. 2011). Alkali modifications of carrageenans are suggested for improved application potential (Campo et al. 2009). Success of commercial reproducibility of highly diverse fucoidan lies in proper characterization with the help of powerful analytical tools (Fitton 2011).

\section{Conclusion}

The research on SP from seaweeds and their wide biological spectrum have skyrocketed in recent years. Their clinical evaluation for possible noble therapeutics development is catching momentum like never before. For above goals to materialize, the underlying molecular mechanisms need to be understood precisely and elucidated clearly. The relation between structure and function should be unraveled by intensive studies. This up-to-date review on this emerging technique is expected to contribute significantly in supplementing background knowledge, kindling interest for future explorations. Further purification steps and investigation on structural features as well as in vivo experiments are needed to test the viability of their use as therapeutic agents. The SP with appreciably few side effects and myriad benefits could potentially be exploited for complementary medicine use and disease management.

Open Access This article is distributed under the terms of the Creative Commons Attribution License which permits any use, distribution, and reproduction in any medium, provided the original author(s) and the source are credited.

\section{References}

Alasalvar C, Shahidi F, Miyashita K, Wanasundara U (2010) Seafood quality, safety, and health applications. In: Alasalvar C, Shahidi F, Miyashita K, Wanasundara U (eds) An overview, in handbook of seafood quality, safety and health applications. WileyBlackwell, Oxford. doi:10.1002/9781444325546.ch1

Albuquerque IR, Queiroz KC, Alves LG, Santos EA, Leite EL, Rocha HA (2004) Heterofucans from Dictyota menstrualis have anticoagulant activity. Braz J Med Biol Res 37:167-171

Ananthi S, Raghavendran HR, Sunil AG, Gayathri V, Ramakrishnan G, Vasanthi HR (2009) In vitro antioxidant and in vivo antiinflammatory potential of crude polysaccharide from Turbinaria ornata (Marine Brown Alga). Food Chem Toxicol 48:187-192 
Bandyopadhyay SS, Navid MH, Ghosh T, Schnitzler P, Ray B (2011) Structural features and in vitro antiviral activities of sulfated polysaccharides from Sphacelaria indica. Phytochemistry 72:276-283

Barahona T, Chandía NP, Encinas MV, Matsuhiro B, Zúñiga EA (2011) Antioxidant capacity of sulfated polysaccharides from seaweeds. A kinetic approach. Food Hydrocol 25:529-535

Bilan MI, Vinogradova EV, Shashkov AS, Usov AI (2007) Structure of a highly pyruvylated galactan sulfate from the Pacific green alga Codium yezoense (Bryopsidales, Chlorophyta). Carbohydr Res 342:586-596

Boisson-Vidal C, Haroun F, Ellouali M, Blondin C, Fischer AM, De Agostini A, Jozefonvicz J (1995) Biological activities of polysaccharide from marine algae. Drugs Fut 20:1237-1249

Bouhlal R, Haslin C, Chermann JC, Colliec-Jouault S, Sinquin C, Somin G, Cerantola S, Riadi H, Bourgougnon N (2011) Antiviral activities of sulfated polysaccharides isolated from Sphaerococcus coronopifolius (Rhodophytha, Gigartinales) and Boergeseniella thuyoides (Rhodophyta, Ceramiales). Mar Drugs 9:1187-1209

Camara RB, Costa LS, Fidelis GP, Nobre LT, Dantas-Santos N, Cordiro SL, Costa MS, Alves LG, Rocha HA (2011) Heterofucans from the brown seaweed Canistrocarpus cervicornis with anticoagulant and antioxidant activities. Mar Drugs 24:124-138

Campo VL, Kawano DF, Silva DBD Jr, Carvalho I (2009) Carrageenans: biological properties, chemical modifications and structural analysis - a review. Carbohydr Polym 77:167-180

Cassolato JEF, Noseda MD, Pujol CA, Pellizzari FM, Damonte EB, Duarte MER (2008) Chemical structure and antiviral activity of the sulfated heterorhamnan isolated from the green seaweed Gayralia oxysperma. Carbohydr Res 343:3085-3095

Charles AL, Chang C-K, Wu M-L, Huang T-C (2007) Studies on the expression of liver detoxifying enzymes in rats fed seaweed (Monostroma nitidum). Food Chem Toxicol 45:2390-2396

Chattopadhyay K, Mateu CG, Mandal P, Pujol CA, Damonte EB, Ray B (2007) Galactan sulfate of Grateloupia indica: isolation, structural features and antiviral activity. Phytochemistry 86:1428-1435

Chen JH, Lim JD, Sohn EH, Choi YS, Han ET (2009) Growthinhibitory effect of a fucoidan from brown seaweed Undaria pinnatifida on Plasmodium parasites. Parasitol Res 104:245-250

Ciancia M, Quintana I, Vizcargüénaga MI, Kasulin L, de Dios A, Estevez JM, Cerezo AS (2007) Polysaccharides from the green seaweeds Codium fragile and $C$. vermilara with controversial effects on hemostasis. Int J Biol Macromol 41:641-649

Clement MJ, Tissot B, Chevolot L, Adjadj E, Du Y, Curmi PA, Daniel R (2010) NMR characterization and molecular modeling of fucoidan showing the importance of oligosaccharide branching in its anticomplementary activity. Glycobiol 20:883-894

Collen PN, Sassi J-F, Rogniaux H, Marfaing H, Helbert W (2011) Ulvan lyases isolated from the flavobacteria Persicivirga ulvanivorans are the first members of a new polysaccharide lyase family. J Biol Chem 286:42063-42071

Costa LS, Fidelis GP, Cordeiro SL, Oliveira RM, Sabry DA, Câmara RBG, Nobre LTDB, Costa MSSP, Almeida-Lima J, Farias EHC, Leite EL, Rocha HAO (2010) Biological activities of sulfated polysaccharides from tropical seaweeds. Biomed Pharmacother 64:21-28

Costa LS, Telles CB, Oliveira RM, Nobre LT, Dantas-Santos N, Camara RB, Costa MS, Almeida-Lima J, Melo-Silveira RF, Albuquerque IR, Leite EL, Rocha HA (2011a) Heterofucan from Sargassum filipendula induces apoptosis in HeLa cells. Mar Drugs 9:603-614

Costa LS, Fidelis GP, Telles CB, Dantas-Santos N, Camara RB, Cordiro SL, Costa MS, Almeida-Lima J, Melo-Silveira RF, Oliveira RM, Albuquerque IR, Andrade GP, Rocha HA (2011b) Antioxidant and antiproliferative activities of heterofucans from the seaweed Sargassum filipendula. Mar Drugs 9:952-966
Coura CO, de Araújo IW, Vanderlei ES, Rodrigues JA, Quinderé AL, Fontes BP, de Queiroz IN, de Menezes DB, Bezerra MM, E Silva AA, Chaves HV, Jorge RJ, Evangelista JS, Benevides NM (2011) Antinociceptive and anti-inflammatory activities of sulphated polysaccharides from the red seaweed Gracilaria cornea. Basic Clin Pharmacol Toxicol. doi:10.1111/j.1742-7843. 2011.00811.x

Croci DO, Cumashi A, Ushakova NA, Preobrazhenskaya ME, Piccoli A, Totani L, Ustyuzhanina Ne, Bilan MI, USov AI, Grachev AA, Morozevich GE, Berman AE, Sanderson CJ, Kelly M, DiGregorio P, Rossi C, Tinari N, Iacobelli S, Rabinovich GA, Nifantiev NE (2011) Fucans, but not fucomannoglucuronans, determine the biological activities of sulfated polysaccharides from Laminaria saccharina brown seaweed. PLoS One 28:e17283. doi: 10.1371/journal.pone.0017283

de Araújo IWF, Vanderlei ESO, Rodrigues JAG, Coura CO, Quinderé ALG, Fontes BP, de Queiroz INL, Jorge RJB, Bezerra MM, Silva AAR, Chaves HV, Monteiro HSA, de Paula RCM, Benevides NMB (2011) Effects of a sulfated polysaccharide isolated from the red seaweed Solieria filiformis on models of nociception and inflammation. Carbohydr Polym 86:1207-1215

de Sousa AA, Benevides NM, de Freitas Pires A, Fiúza FP, Queiroz MG, Morais TM, Pereira MG, Assreuy AM (2011a) A report of a galactan from marine alga Gelidium crinale with in vivo antiinflammatory and antinociceptive effects. Fundam Clin Pharmacol. doi:10.1111/j.1472-8206.2011.01001.x

de Sousa OVE, de Araújo IW, Quinderé AL, Fontes BP, Eloy YR, Rodrigues JA, Silva AA, Chaves HV, Jorge RJ, de Menezes DB, Evangelista JS, Bezerra MM, Benevides NM (2011b) The involvement of the HO-1 pathway in the anti-inflammatory action of a sulfated polysaccharide isolated from the red seaweed Gracilaria birdiae. Inflamm Res 60:1121-1130

Devaki T, Sathivel A, BalajiRaghavendran HR (2009) Stabilization of mitochondrial and microsomal function by polysaccharide of Ulva lactuca on D-Galactosamine induced hepatitis in rats. Chem Biol Interact 177:83-88

Du X, Jiang S, Xin X, Li J, Geng M, Jiang H (2010) MS80, a novel sulfated polysaccharide, inhibits CD40-NF-kappaB pathway via targeting RIP2. Mol Cell Biochem 337:277-285

Ermakova S, Sokolova R, Kim SM, Um BH, Isakov V, Zvyagintseva T (2011) Fucoidans from brown seaweeds Sargassum hornery, Eclonia cava, Costaria costata: structural characteristics and anticancer activity. Appl Biochem Biotechnol 164:841-850

Farias WR, Lima PC, Rodrigues NV, Siqueira RC, Amorim RM, Pereira MG, Assreuy AM (2011) A novel antinociceptive sulphated polysaccharide of the brown marine alga Spatoglossum schroederi. Nat Prod Commun 6:863-866

Fernández PV, Estevez JM, Cerezo As, Ciancia M (2012) Sulfated $\beta$ D-mannan from green seaweed Codium vermilara. Carbohydr Polym 87:916-919

Fitton JH (2011) Therapies from fucoidan; multifunctional marine polymers. Mar drugs 9:1731-1760

Foley SA, Mulloy B, Tuohy MG (2011) An unfractionated fucoidan from Ascophyllum nodosum: extraction, characterization, and apoptotic effects in vitro. J Nat Prod 74:1851-1861

Fonseca RJ, Oliveira SN, Melo FR, Pereira MG, Benevides NM, Mourao PA (2008) Slight differences in sulfation of algal galactans account for differences in their anticoagulant and venous antithrombotic activities. Thromb Haemost 99:539-545

Freguin-Bouilland C, Alkhatib B, David N, Lallemand F, Henry JP, Godin M, Thuillez C, Plissonnier D (2007) Low molecular weight fucoidan prevents neointimal hyperplasia after aortic allografting. Transplantation 15:1234-1241

Frenette PS, Weiss L (2000) Sulfated glycans induce rapid hematopoietic progenitor cell mobilization: evidence for selectindependent and independent mechanisms. Blood 96:2460-2468 
Fukuta K, Nakamura T (2008) Induction of hepatocyte growth factor by fucoidan and fucoidan-derived oligosaccharides. J Pharm Pharmacol 60:499-503

Gao Y, Li C, Yin J, Shen J, Wang H, Wu Y, Jin H (2011) Fucoidan, a sulfated polysaccharide from brown algae, improves cognitive impairment induced by infusion of $\mathrm{A} \beta$ peptide in rats. Environ Toxicol Pharmacol. doi:10.1016/j.etap.2011.12.022

Ghosh T, Pujol CA, Damonte EB, Sinha S, Ray B (2009) Sulfated xylomannans from the red seaweed Sebdenia polydactyla: structural features, chemical modification and antiviral activity. Antivir Chem Chemother 19:235-242

Graça JRV, Bezerra MM, Lima V, Ariévilo J, Rodrigues G, Monteiro DLS, Quinderé ALG, Amorim RCDN, de Paula RCM, Benevides NMB (2011) Effect of a crude sulfated polysaccharide from Halymenia floresia (Rhodophyta) on gastrointestinal smooth muscle contractility. Braz Arch Biol Technol 54:907-916

Haneji K, Matsuda T, Tomita M, Kawakami H, Ohshiro K, Uchihara JN, Masuda M, Takasu N, Tanaka Y, Ohta T, Mori N (2005) Fucoidan extracted from Cladosiphon okamuranus Tokida induces apoptosis of human T-cell leukemia virus type 1-infected T-cell lines and primary adult T-cell leukemia cells. Nutr Cancer 52:189-201

Hlawaty H, Suffee N, Sutton A, Oudar O, Haddad O, Olliver V, Laguillier-Morizot C, Gattegno L, Letourneur D, Charnaux N (2011) Low molecular weight fucoidan prevents intimal hyperplasia in rat injured thoracic aorta through the modulation of matrix metalloproteinase-2 expression. Biochem Pharmacol $15: 233-243$

Hong SW, Jung KH, Lee HS, Zheng HM, Choi MJ, Lee C, Hong SS (2011) Suppression by fucoidan of liver fibrogenesis via the TGF- $\beta /$ Smad pathway in protecting against oxidative stress. Biosci Biotechnol Biochem 75:833-840

Hu T, Liu D, Chen Y, Wu J, Wang S (2010) Antioxidant activity of sulfated polysaccharide fractions extracted from Undaria pinnitafida in vitro. Int J Biol Macromol 46:193-198

Huang L, Wen K, Gao X, Liu Y (2010) Hypolipidemic effect of fucoidan from Laminaria japonica in hyperlipidemic rats. Pharm Biol 48:422-426

Hwang PA, Chien SY, Chan YL, Lu MK, Wu CH, Kong ZL, Wu CJ (2011) Inhibition of Lipopolysaccharide (LPS)-induced inflammatory responses by Sargassum hemiphyllum sulfated polysaccharide extract in RAW 264.7 macrophage cells. J Agric Food Chem 59:2062-2068

Jiang HD, Guan HS (2009) MS80, a novel sulfated oligosaccharide, inhibits pulmonary fibrosis by targeting TGF-beta1 both in vitro and in vivo. Acta Pharmacol Sin 30:973-979

Jiao G, Yu G, Zhang J, Ewart HS (2011) Chemical structures and bioactivities of sulfated polysaccharides from marine algae. Mar Drugs 9:196-223

Jiménez-Escrig A, Gómez-Ordóñez E, Rupérez P (2011) Seaweed as a source of novel nutraceuticals: sulfated polysaccharides and peptides. Adv Food Nutr Res 64:325-337

Jin JO, Song MG, Kim YN, Park JI, Kwak JY (2010) The mechanism of fucoidan-induced apoptosis in leukemic cells: involvement of ERK1/2, JNK, glutathione, and nitric oxide. Mol Carcinog 49:771-782

Josephine A, Veena CK, Amudha G, Preetha SP, Varalakshmi P (2007) Protective role of sulphated polysaccharides in abating the hyperlipidemic nephropathy provoked by cyclosporine A. Arch Toxicol 81:371-379

Kawashima T, Murakami K, Nishimura I, Nakano T, Obata A (2011) A sulfated polysaccharide, fucoidan, enhances the immunomodulatory effects of lactic acid bacteria. Int $\mathrm{J}$ Mol Med. doi: 10.3892/ijmm.2011.854
Kazłowski B, Chiu Y-H, Kazłowska K, Pan C-L, Wu C-J (2012) Prevention of Japanese encpalitis virus infections by low-degreepolymerisation sulfated saccharides from Garcilaria sp. and Monostroma nitidum. Food Chem. doi:10.1016/j.foodchem. 2012.01.106

Kim K-J, Lee O-H, Lee B-Y (2010) Fucoidan, a sulfated polysaccharide, inhibits adipogenesis through the mitogen-activated protein kinase pathway in 3T3-L1 preadipocytes. Life Sci $86: 21-22$

Kim J-K, Cho ML, Karnjanapratum S, Shin I-S, You SG (2011) In vitro and in vivo immunomodulatory activity of sulfated polysaccharides from Enteromorpha prolifera. Int J Biol Macromol 49:1051-1058

Kim M, Yim JH, Kim S-Y, Kim HS, Lee WG, Kim SJ,Kang P-S, Lee C-K (2012) In vitro inhibition of influenza A virus infection by marine microalga-derived sulfated polysaccharide p-KG03. Antiviral Res 93:253-259

Kima MH, Joo HG (2008) Immunostimulatory effects of fucoidan on bone marrow-derived dendritic cells. Immunol Lett 115:138-143

Kumaran S, Deivasigamani B, Alagappan K, Sakthivel M, Karthikeyan R (2010) Antibiotic resistant Escherichia coli strains from seafood and its susceptibility to seaweed extracts. Asian Pac J Trop Med 3:977-981

Lahaye M, Robic A (2007) Structure and functional properties of ulvan, a polysaccharide from green seaweeds. Biomacromolecules 8:1765-1774

Leibbrandt A, Meier C, König-Schuster M, Weinmüllner R, Kalthoff D, Pflugfelder B, Graf P, Frank-Gehrke B, Beer M, Fazekas T, Unger H, Prieschl-Grassauer E, Grassauer A (2010) Iotacarrageenan is a potent inhibitor of influenza A virus infection. PLoS One 5(12):e14320. doi:10.1371/journal.pone.0014320

Leiro JM, Castro R, Arranz JA, Lamas J (2007) Immunomodulating activities of acidic sulphated polysaccharides obtained from the seaweed Ulva rigida C. Agardh. Int Immunopharmacol 7:879-888

Li B, Lu F, Wei X, Zhao R (2008) Fucoidan: structure and bioactivity. Molecules 13:1671-1695

Li H, Mao W, Zhang X, Qi X, Chen Y, Chen Y, Xu J, Zhao C, Hou Y, Yang Y, Li N, Wang C (2011) Structural characterization of an anticoagulant-active sulfated polysaccharide isolated from green alga Monostroma latissimum. Carbohydr Polym 85:394-400

Lins KO, Bezerra DP, Alves AP, Alencar NM, Lima MW, Torres VM, Farias WR, Pessoa C, de Moraes MO, Costa-Lotufo LV (2009) Antitumor properties of a sulfated polysaccharide from the red seaweed Champia feldmannii (Diaz-Pifferer). J Appl Toxicol 29:20-26

Magalhaes KD, Costa LS, Fidelis GP, Oliveira RM, Nobre LT, Dantas-Santos N, Camara RB, Albuquerque IR, Cordeiro SL, Sabry DA, Costa MS, Alves LG, Rocha HA (2011) Anticoagulant, antioxidant and antitumor activities of heterofucans from the seaweed Dictyopteris delicatula. Int J Mol Sci 12:3352-3365

Mandal P, Mateu CG, Chattopadhyay K, Pujol CA, Damonte EB, Ray B (2007) Structural features and antiviral activity of sulphated fucans from the brown seaweed Cystoseira indica. Antivir Chem Chemother 18:153-162

Mandal P, Pujol CA, Carlucci MJ, Chattopadhyaya K, Damonte EB, Ray B (2008) Anti-herpetic activity of a sulfated xylomannan from Scinaia hatei. Phytochemistry 69:2193-2199

Mao W-J, Fang F, Li H-Y, Qi X-H, Sun H-H, Chen Y, Guo S-D (2008) Heparinoid-active two sulfated polysaccharides isolated from marine green algae Monostroma nitidum. Carbohydr Polym 74:834-839

Marques CT, de Azevedo TCG, Nascimento MS, Medeiros VP, Alves LG, Benevides NMB, Rocha HAO, Leite EL (2012) Sulfated fucans extracted from algae Padina gymnospora have 
anti-inflammatory effect. Rev Bras Farmacogn 22. doi:10.1590/ S0102-695X2011005000206

Maruyama H, Tanaka M, Hashimoto M, Inoue M, Sasahara T (2007) The suppressive effect of Mekabu fucoidan on an attachment of Cryptosporidium parvum oocysts to the intestinal epithelial cells in neonatal mice. Life Sci 80:775-781

Matsumoto S, Nagaoka M, Hara T, Kimura-Takagi I, Mistuyama K, Ueyama S (2004) Fucoidan derived from Cladosiphon okamuranus Tokida ameliorates murine chronic colitis through the down-regulation of interleukin-6 production on colonic epithelial cells. Clin Exp Immunol 136:432-439

Medeiros VP, Queiroz KC, Cardoso ML, Monteiro GR, Oliveira FW, Chavante SF, Guimaraes LA, Rocha HA, Leite EL (2008) Sulfated galactofucan from Lobophora variegata: anticoagulant and anti-inflammatory properties. Biochemistry (Mosc.) 73:1018-1024

Murakami K, Aoki H, Nakamura S, Nakamura S, Takikawa M, Hanzawa M, Kishimoto S, Hattori H, Tanaka T, Sato Y, Ishihara M (2010) Hydrogel blends of chitin/chitosan, fucoidan and alginate as healing-impaired wound dressings. Biomaterials 31:83-90

Nakamura S, Nambu M, Ishizuka T, Hattori H, Kanatani Y, TAkase B, Kishimoto S, Amano Y, Aoki H, Kiyosawa T, Ishihara M, Maehara T (2008) Effect of controlled release of fibroblast growth factor-2 from chitosan/fucoidan micro complex-hydrogel on in vitro and in vivo vascularization. J Biomed Mater Res A 85:619-627

Pomin VH (2009) An overview about the structure-function relationship of marine sulphated polysaccharides with regular chemical structures. Biopolymers 91(8):601-609

Pomin VH, Mourao PAS (2008) Structure, biology, evolution, and medical importance of sulfated fucans and galactans. Glycobiology 18:1016-1027

Pushpamali WA, Nikapitiya C, De Zoysa M, Whang I, Kim SJ, Lee J (2008) Isolation and purification of an anticoagulant from fermented red seaweed Lomentaria catenata. Carbohydr Polym 73:274-279

Qianqian W, Shuang M, Hourong X, Min Z, Jingmin C (2011) Purification and the secondary structure of fucoidanase from Fusarium sp. LD8. Evid Based Complement Altern Med. doi: $10.1155 / 2011 / 196190$

Raghavendran HR, Sathivel A, Devaki T (2005) Effect of Sargassum polycystum (Phaeophyceae)-sulphated polysaccharide extract against acetaminophen-induced hyperlipidemia during toxic hepatitis in experimental rats. Mol Cell Biochem 276:89-96

Recalde MP, Noseda MD, Pujol CA, Carlucci MJ, Matulewicz MC (2009) Sulfated mannans from the red seaweed Nemalion helminthoides of the South Atlantic. Phytochemistry 70:1062-1068

Robic A, Sassi J-F, Dion P, Lerat Y, Lahaye M (2009) Seasonal variability of physicochemical and rheological properties of ulvan in two Ulva species (Chlorophyta) from the Brittany coast. J Phycol 45:962-973

Rodriguez-Jasso RM, Mussatto SI, Pastrana L, Aguilar CN, Teixeira JA (2011) Microwave-assisted extraction of sulfated polysaccharides (fucoidan) from brown seaweed. Carbohydr Polym 86:1137-1144

Saha S, Navid MH, Bandyopadhyay SS, Schnitzler P, Ray B (2012) Sulfated polysaccharides from Laminaria angustata: structural features and in vitro antiviral activities. Carbohydr Polym 87:123-130

Sathivel A, Raghavendran HR, Srinivasan P, Devaki T (2008) Antiperoxidative and anti-hyperlipidemic nature of Ulva lactuca crude polysaccharide on D-galactosamine induced hepatitis in rats. Food Chem Toxicol 46:3262-3267

Senni A, Pereira J, Gueniche F, Delbarre-Ladrat C, Sinquin C, RAtiskol J, Godeau G, Fischer A-M, Helley D, Colliec-Jouault S (2011) Marine polysaccharides: a source of bioactive molecules for cell therapy and tissue engineering. Mar Drugs 9:1664-1681

Sezer AD, Cevher E, Hatipoglu F, Ogurtan Z, Bas AL, Akbuga J (2008) Preparation of fucoidan-chitosan hydrogel and its application as burn healing accelerator on rabbits. Biol Pharm Bull 31:2326-2333

Souza BWS, Cerqueira MA, Bourbon AI, Pinheiro AC, Martins JT, Teixeira JA, Coimbra MA, Vicente AA (2012) Chemical characterization and antioxidant activity of sulfated polysaccharide from the red seaweed Gracilaria birdiae. Food Hydrocol 27:287-292

Toskas G, Hund R-D, Laourine E, Cherif C, Smyrniotopoulos V, Roussis V (2011) Nanofibers based on polysaccharides from the green seaweed Ulva rigida. Carbohydr Polym 84:1093-1102

Trinchero J, Ponce NM, Córdoba OL, Flores ML, Pampuro S, Stortz CA, Salomón H, Turk G (2009) Antiretroviral activity of fucoidans extracted from the brown seaweed Adenocystis utricularis. Phytother Res 23:707-712

Tuvikene R, Truus K, Vaher M, Kailas T, Martin G, Kersen P (2006) Extraction and quantification of hybrid carrageenans from the biomass of the red algae Furcellaria lumbricalis and Coccotylus truncatus. Proc Estonian Acad Sci Chem 55:40-53

Veena CK, Josephine A, Preetha SP, Varalakshmi P (2007) Beneficial role of sulfated polysaccharides from edible seaweed Fucus vesiculosus in experimental hyperoxaluria. Food Chem 100:1552-1559

Vishchuk OS, Ermakova SP, Zvyagintseva TN (2011) Sulfated polysaccharides from brown seaweeds Saccharina japonica and Undaria pinnatifida: isolation, structural characteristics, and antitumor activity. Carbohydr Res 346:2769-2776

Wang J, Zhang Q, Zhang Z, Li Z (2008) Antioxidant activity of sulfated polysaccharide fractions extracted from Laminaria japonica. Int J Biol Macromol 42:127-132

Wijesekara I, Pangestuti R, Kim SK (2011) Biological activities and potential health benefits of sulphated polysaccharides derived from marine algae. Carbohydr Polym 84:14-21

Wijesinghe WAJP, Athukorala Y, Jeon Y-J (2011) Effect of anticoagulative sulfated polysaccharide purified from enzymeassistant extract of a brown seaweed Ecklonia cava on Wistar rats. Carbohydr Polym 86:917-921

Yang Y, Liu D, Wu J, Chen Y, Wang S (2011) In vitro antioxidant activities of sulfated polysaccharide fractions extracted from Corallina officinalis. Int J Biol Macromol 49:1031-1037

Ye H, Wang K, Zhou C, Liu J, Zeng X (2008) Purification, antitumor and antioxidant activities in vitro of polysaccharides from the brown seaweed Sargassum pallidum. Food Chem 111:428-432

Yuan H, Song J, Li X, Ning L, Song L (2011) Enhanced immunostimulatory and antitumor activity of different derivatives of $\kappa$-carrageenan oligosaccharides from Kappaphycus striatum. J Appl Phycol 23:59-65 